\title{
Integration of GIS and Modeling to Study Soil Characterization, Evaluation and Sensitivity to Degradation of some Alluvial Deposits, Egypt
}

\author{
Yehia, H. A., Fayed, R. I., and Rateb, K. A. ${ }^{1}$
}

\begin{abstract}
The present study aimed to 1) characterize the main soil units, 2) evaluate the land capability and suitability, and 3) use quantitative method to map the environmental sensitivity area for desertification for some Alluvial deposits, West Delta, Egypt, through coupling between Geostatistical analysis and ALES-Arid model for land evaluation in Geographic Information System (GIS) Environment. Geostatistical analysis was carried out to map the spatial distribution of the soil characteristics, and then extract the soil mapping units from the overlaying different soil character layers in GIS environment. Finally, land capability was calculated for each soil mapping unit.
\end{abstract}

To categorize soil properties, 40 soil profiles were dug to $150 \mathrm{~cm}$ depth, and laboratory analysis indicted that the soil is characterized by clayey texture and low salinity. The results of spatial variability and dependence in the surface layer indicate that the best fitting semi-variogram models were the gaussian model for soil salinity and SAR and the spherical model for $\mathrm{CaCO}_{3}$ and Organic matter content and the exponential model for soil depth. In the same time the optimum sampling distance for any further study of EC, SAR, $\mathrm{CaCO}_{3}$, Organic matter content and soil depth were 191, 242, 751, 927 and $504 \mathrm{~m}$, respectively. Six soil units were dominated namely, low saline deep clayey soil $(21.10 \%)$, moderately saline deep clayey soil $(61.19 \%)$, highly saline deep clayey soil $(9.62 \%)$, low saline shallow clayey soil $(2.65 \%)$, moderately saline shallow clayey soil $(5.00 \%)$ and highly saline shallow clayey soil $(0.44 \%)$. Calculated Desertification Sensitivity Index (DSI) showed that most of the study area (64\% of the total area) is very low sensitive to desertification and about $36 \%$ of the total area was not affected.

The land evaluation results for the study area shows that the capability class $\mathrm{C2}(\mathrm{Kh})$, which indicated moderate land capability with hydraulic conductivity limiting factor covered an area about $75.80 \%$ of the total area and $\mathrm{C} 2(\mathrm{Kh}, \mathrm{Ec})$, which indicated moderate capability with hydraulic conductivity and soil salinity as limiting factors covered an area about $24.20 \%$ of the total area. The suitability results show that the area suitable for some crops (fruit trees, field crop and vegetables) but under specific management practices and the main limitations were soil depth, soil salinity, and hydraulic conductivity.

Keywords: geostatistical analysis, GIS, soil units, kriging analysis, land evaluation, environmental sensitivity.

\footnotetext{
${ }^{1}$ Soil salinity and alkalinity lab; soil, water and environment research institute (SWERI), Giza

Received November, 2013, Accepted December 26, 2013
}

\section{INTRODUCTION}

Soil mapping is a process of determining the spatial distribution of physical, chemical and biological soil properties and presenting then in an understandable and interpretable form to various users. It, in generally, consists of the following steps: project planning; preparation for fieldwork; photo-interpretation and preprocessing of auxiliary data; field data collection and laboratory analysis; data input and organization and Presentation and distribution of soil survey products, (Dent \& Young, 1981). Land evaluation plays an important role in the development of a sustainable agriculture (Davidson, 2002). For long term productivity, soils must have a good and right soil management. Depending on this, soil survey works become more important spontaneously (Özsoy and Aksoy, 2007). The agricultural land evaluation methodology is applied to land mapping units for computing a suitability index, based on the value of several soil and environmental indicators, which characterize these land mapping units. The natural land mapping units are delineated using various criteria and thematic layers, but most times the approach is subjective. GIS, geomorphometry, remote sensing and geostatistics bring the possibility to objectively delineate most suitable natural land mapping units for applying the agricultural land evaluation methodology (Iuliana, 2011). The results proved that using RS and GIS technologies and integrating DEM, satellite data and ancillary data are very powerful tool for soil survey and GIS provide necessary procedures for soil survey and mapping works (Aksoy, et. al. 2009). On the other hand, geostatistics considers the spatial dependence of soil properties, but it presents the disadvantage that it does not consider the knowledge about the pedologic and geologic differences in landscape, the natural limits, the relief, etc., and it requires an intensive sampling (Heuvelinks and Bierkens, 1992). A soil map delineation can present an internal variation that affects the certainty of the predictions about the soil properties (Rey and Ovalles, 1997). Therefore, results generated by geostatistical analysis of soil attributes evaluated inside mapping units, could be included in a Geographical Information System (GIS) in which the databases would allow to examine the spatial behavior 
of the different soil properties in areas of interest (McKenzie and Austin, 1993). Geostatistical methods were developed to create mathematical models of spatial correlation structures with a variogram as the quantitative measure of spatial correlation (Wagner Lourenco et al. 2010). Bakr et. al. 2012. Identifying the appropriate parameters as well as choosing the suitable spatial and temporal scale, are essential for correctly identifying the ecosystem and assessing its sensitivity to desertification. In this case study, the standard MEDALUS approach was used in two time periods (1984 and 2008) to evaluate the impacts of the reclamation processes that take place in the Bustan 3 area, Egypt. The adjusted MEDALUS approach for 2008 was applied by adding new parameters to the SQI and extending the quality indicators to include an IWQI. The results clearly elucidate the role that humans play in accelerating, slowing, or eliminating desertification processes. In a fragile, vulnerable agro-ecosystem such as the Bustan 3 area, high sensitivity to desertification exists. Thus, decision-makers should give more attention to the most sensitive areas to desertification. Results of this study show that plant cover, management, and irrigation water quality dramatically impact desertification processes. Access to suitable irrigation water may remain problematic. However, the management of such areas can be improved much more easily. Finally, the monitoring of desertification processes over long periods of time provides valuable information and is highly recommended for proper land use planning as well as sustainable development.

\section{MATERIALIS AND METHODS}

Area Study: The study area is located west of the Nile delta near Damanhour district, El Behira Governorate, Egypt and represents the alluvial soil. It's covered about 680 fed. It consists of group of agricultural associations called El Metalab, El Baranis, El Ghaffar, El Waza El Bahria, El Waza El Qablia, El Kahila, El Qabli, El wasad and El Bakria with areas of 84.44, 64.56, 95.68, $39.56,71.78, \quad 90.25, \quad 54.67, \quad 84.65$ and 94.81 respectively. The study area located between $31^{\circ} 00^{\prime} 30^{\prime \prime} \mathrm{N}$ and $31^{\circ} 02^{\prime} 00^{\prime \prime} \mathrm{N}$ and $30^{\circ} 30^{\prime} 00^{\prime \prime} \mathrm{E}$ and $30^{\circ} 31^{\prime} 00^{\prime \prime} \mathrm{E}$ as shown in map (1). The main irrigation and drainage systems used were surface, consisted of four main irrigation canals with a total length of about $10.8 \mathrm{~km}$, the main irrigation canal was El-Bashnawet irrigation canal with total length of $2.74 \mathrm{Km}$, and three main drains with a total length of $8.9 \mathrm{~km}$, the main one was Kafr Bani Helal drain with total length about 3.93 $\mathrm{Km}$ as shown in map 2.

Soil sampling design and analysis: Fourty soil profiles were dug to a depth of $80-150 \mathrm{~cm}$. The soil profiles were morphologically described in the field according to FAO (2010), and geo-referenced to UTM coordinate system map (3). The soil samples were prepared and analyzed for chemical, physical and biological characterization according to Page et al. (1982) and Klute, (1986).

Terrain Analysis: Topographic map sheet (1:25000) of Damanhour was digitized using ArcGIS 9.3 to indicate contour lines, spot height, irrigation canal, drainage canal, and main roads were the main input features. Contour lines and spot height input to contour gridder module to generate Digital Elevation Model (DEM). Slope and aspect were derived using spatial analyst.

Land Evaluation: Agricultural Land Evaluation System for arid region (ALES-Arid) is described as a land use decision support system, which is linked directly with integrated databases and coupled with GIS. Through ALES-Arid program, land evaluation algorithms were expressed in notation forms that can be understood by a calculating device. Optimization tools based on land evaluation models are considered very important to formulate decision alternatives. According to (Storie, 1964); six productivity classes were identified as shown in table (1).

The calculation of capability index by ALES-Arid is an indication of land capability according to multiplication method (Abdel Kawy, 2004). ALES-Arid evaluates the suitability for different crops (field crops, vegetables, forage crops, and fruit tress) to identify the optimum land use. Land suitability classes were identified using the matching between standard crop requirements (FAO, 1977, 1985; Sys, 1975; and Sys et al., 1993a, 1993b) and actual land characteristics.

\section{Statistical analysis \\ Descriptive statistical analysis}

Statistical analysis was carried out using Excel spreadsheet. The following classical statistics parameters were calculated: minimum, maximum, mean, standard deviation and coefficient of variation of each soil characteristics according to Webster 1977; and Wilding and Dress, 1983.

\section{Geostatistical analysis \\ The Semi-Variogram}

The semi-variogram is the most important tool in geostatistical applications to soil. It represents the average rate of change of property with distance. It is the basis for modeling the data set and for drawing a contour maps or isarithms according to Burgess\& Webster 1980. 


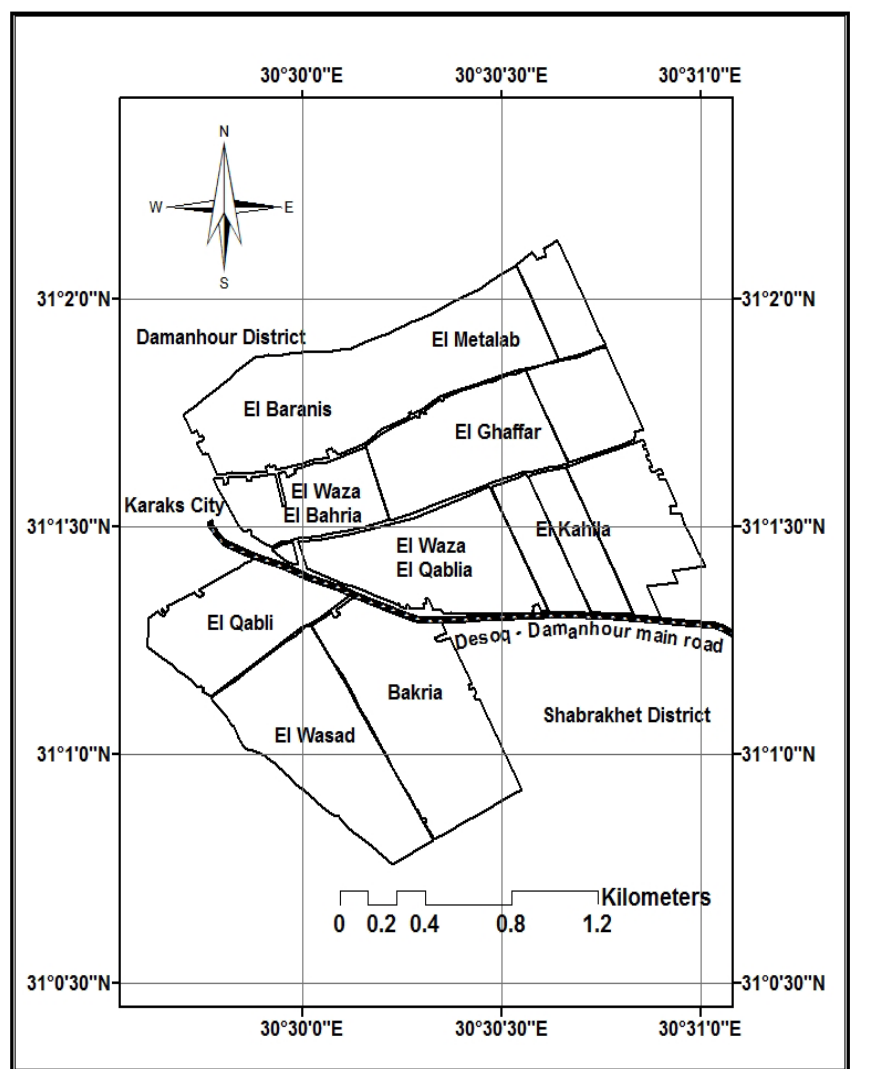

Map 1.General location of the study area and its agricultural associations

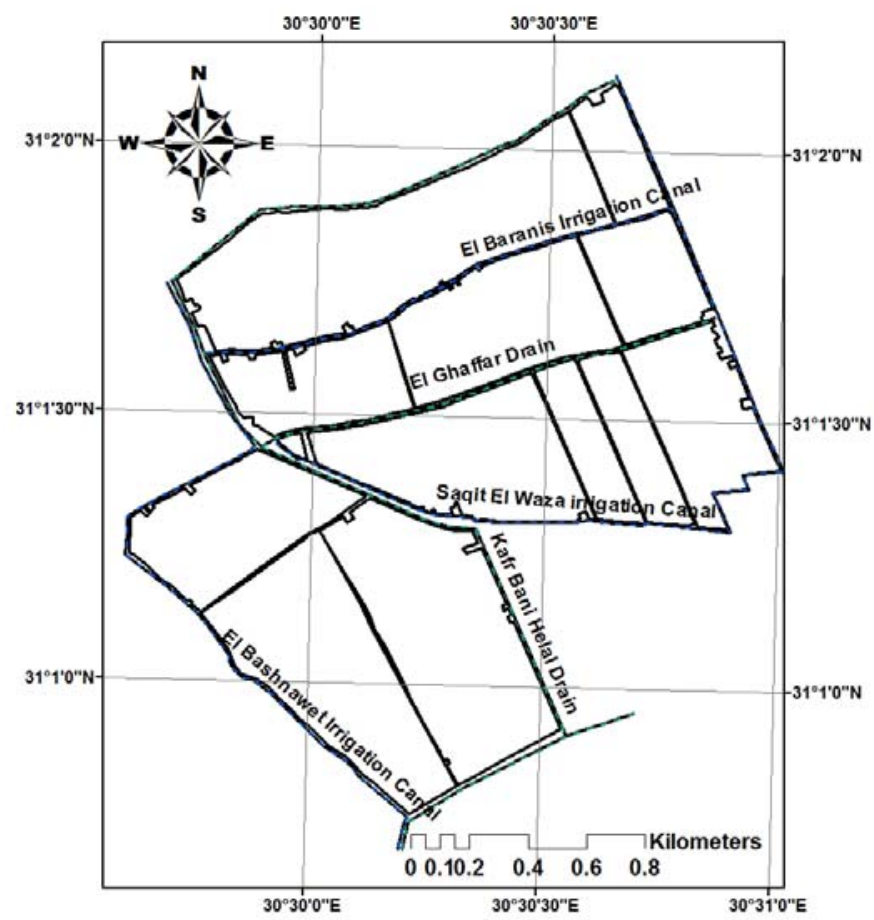

Map 2. Irrigation and drainage systems of the study area 
Table 1.Productivity classes and ratings according to (Storie, 1964)

\begin{tabular}{lcc}
\hline Class & Description & Rating (\%) \\
\hline C1 & Excellent & $80-100$ \\
\hline C2 & Good & $60-80$ \\
\hline C3 & Fair & $40-60$ \\
\hline C4 & Poor & $20-40$ \\
\hline C5 & Very poor & $10-20$ \\
\hline C6 & Non-agriculture & $<10$ \\
\hline
\end{tabular}

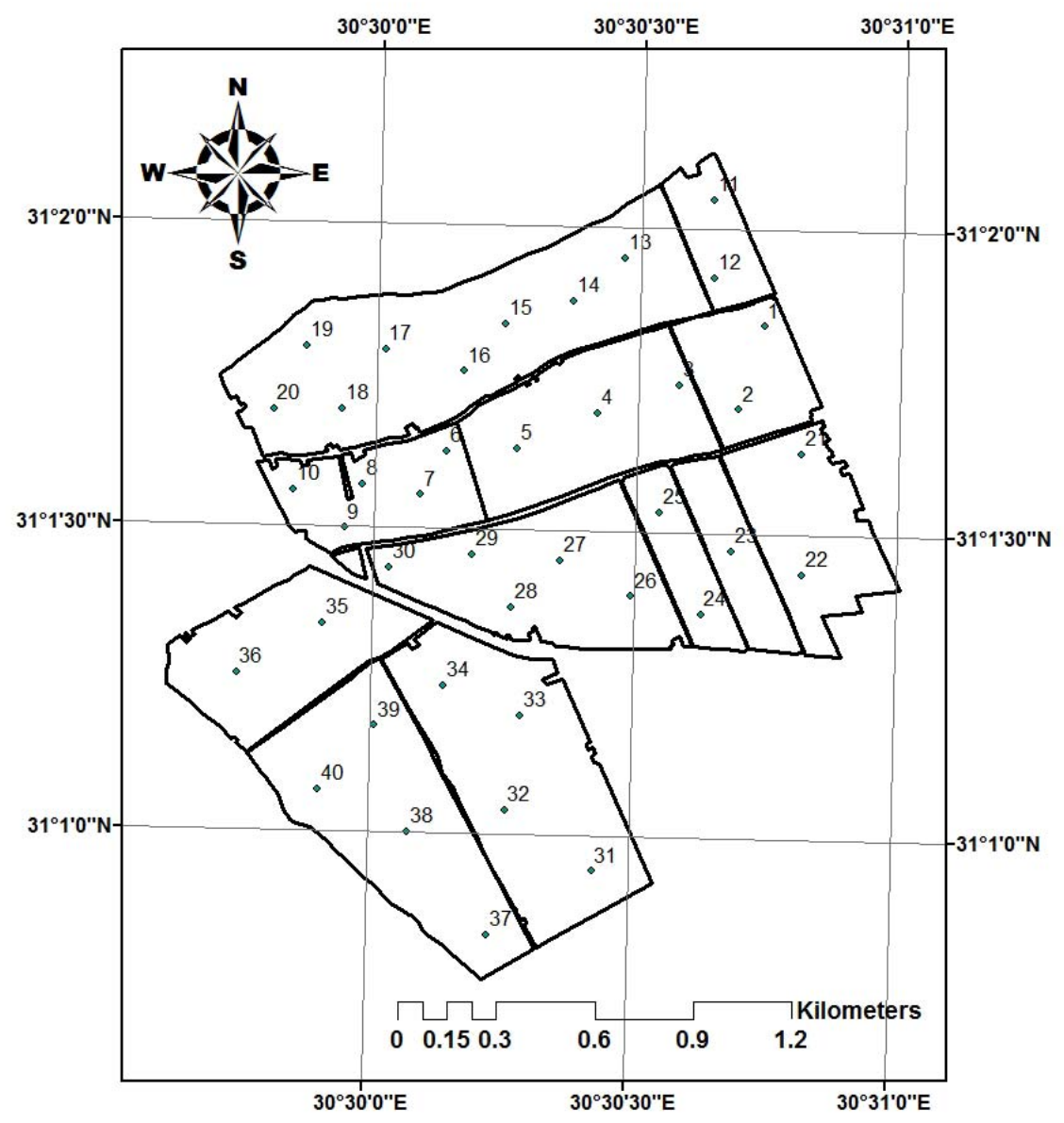

Map 3. Distribution of the soil profiles at the study area

The obtained semi-variogram values for each lag were fitted to one of the semi-variogram function using the GSPLUS GEOSTATISTICAL analysis for environmental sciences software Ver. 5.3.1, Gamma Design (2001).

\section{Punctual Kriging:}

Kriging is a method of interpolation using the weighted local averaging. It is optimal in a sense that the weights are chosen to give unbasied estimates while keeping the estimation variance at minimum (Webster, 1977).
Environmentally Sensitive Areas (ESA): The identification of sensitive areas is based on the hypotheses of MEDALUS project model (Giordane et al., 2008). The model applies a geometrical average of some quality indices, in order to provide sensitivity diagnosis. It assumes that each index has only limited capacity of influence the final value of Environmentally Sensitive Areas (ESA) index and only when several parameters have a high score, an area can be assigned to high sensitivity class. The following three quality indices were computed; Soil Quality Index (SQI), Vegetation Quality Index (VQI), Climatic Quality Index. The methodology is based on classification of 
each quality index obtained as geometric mean of available environmental and anthropogenic parameters. The available parameters are quantified in relation to their influence on the desertification process assigning score to each. The scores assigned to different parameters range between 1 (best value) and 2 (worst value). The final overall ESA index is obtained as a geometrical average of the quality indexes (E.C, 1999). Fig. (1) demonstrates the main flow chart of concepts and studied steps performed in the current study. The main input data for calculating theses indices include topographic map of the study area, climatic data derived from the Ministry of Agriculture. GIS system (i.e. Arc GIS 9) was the main tools in indices computations and ESA's mapping.

1. Mapping Soil Quality Index (SQI): Soil is the dominant factor of the terrestrial ecosystems in the arid and semi arid and dry zones, particularly through its effect on biomass production. Soil quality indicators for mapping ESA's can be related to water availability and erosion resistance (Briggs et al, 1992; Basso et al, 1998). A number of four soil parameters were considered at the current investigation (i.e. parent material, soil texture, soil depth and slope gradient). Weighting factors were assigned to each category of the considered parameters, on basis of OSS, 2004, which were adapted from Medalus project methodology (European Commission 1999). Tables (2 to 5) demonstrate the assigned indexes for different categories of each parameter. The soil Quality Index (SQI) was calculated on basis of the following equation, and classified according to categories shown in table (6).

$$
\text { SQI }=(\mathbf{I p} * \mathbf{I t} * \mathbf{I d} * \mathbf{I s})^{1 / 4}
$$

Ip index of parent material, It index of soil texture, Id index of soil depth, Is index of slope gradient)

Table 2.Classes and assigned weighting index for parent material

\begin{tabular}{lll}
\hline \multicolumn{1}{c}{ Class } & Description & Score \\
\hline 1) Coherent: Limestone, dolomite, non-friable sandstone, hard limestone layer. & Good & 1 \\
\hline 2) Moderately coherent: Marine limestone, friable sandstone & Moderate & 1.5 \\
\hline 3) Soft to friable: Calcareous clay, clay, sandy formation, alluvium and colluviums & Poor & 2 \\
\hline
\end{tabular}

In case of deep Aeolian deposits over a rocky parent material, the Aeolian sediments are considered as parent material.

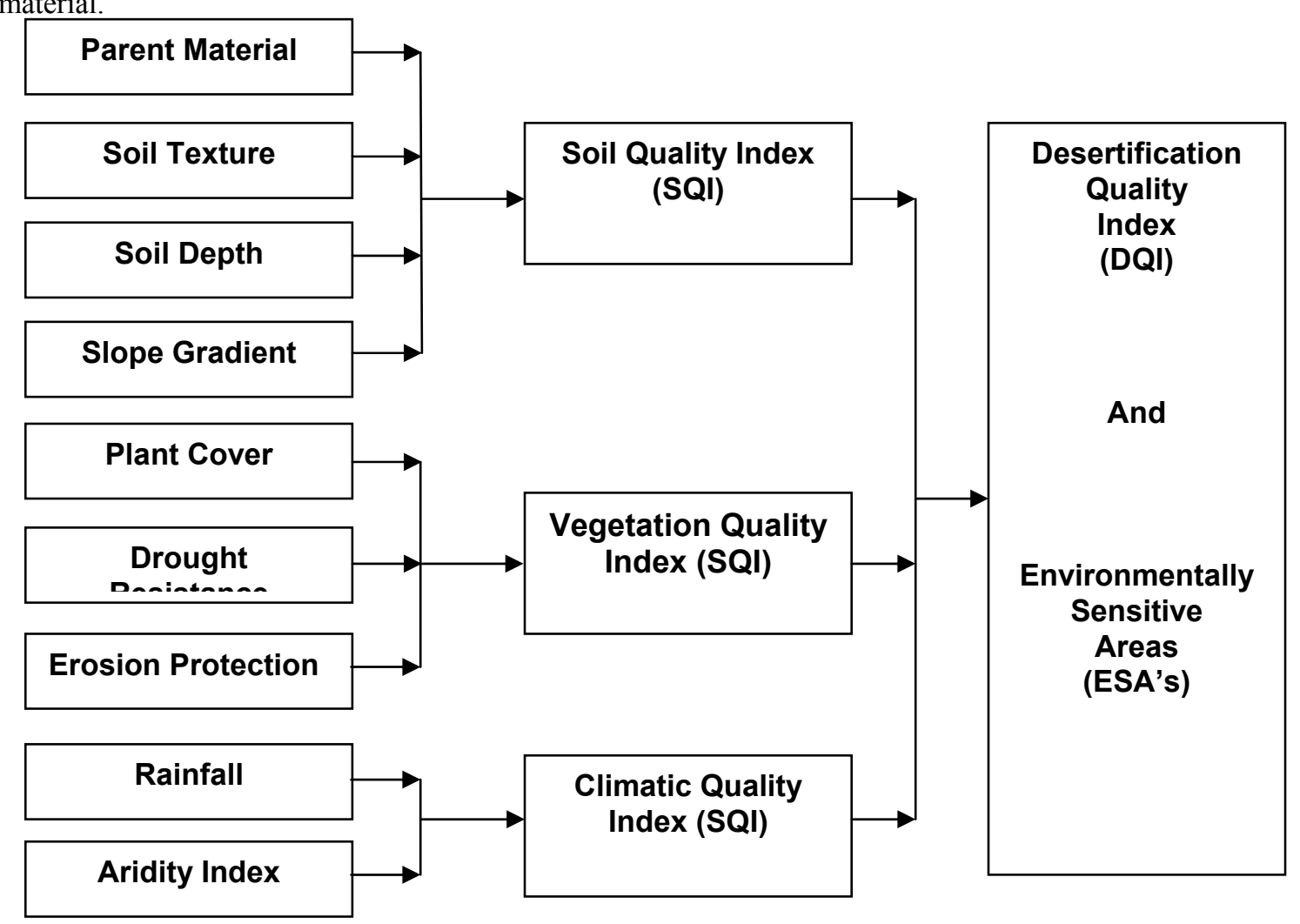

Fig. 1. Flow chart of mapping Environmentally Sensitive Areas (ESA's) 
Table 3. Classes and assigned weighting index for soil depth

\begin{tabular}{lcc}
\hline \multicolumn{1}{c}{ Class } & Description & Score \\
\hline Very deep & Soil thickness is more than 1 meter & 1.00 \\
\hline Moderately deep & Soil thickness ranges from $<1 \mathrm{~m}$ to $0.5 \mathrm{~m}$ & 1.33 \\
\hline Not deep & Soil thickness ranges from $<0.5 \mathrm{~m}$ to $0.25 \mathrm{~m}$ & 1.66 \\
\hline Very thin & Soil thickness $0.15 \mathrm{~m}$ & 2.00 \\
\hline
\end{tabular}

Table 4. Classes and assigned weighting index for soil texture

\begin{tabular}{llcc}
\hline \multirow{2}{*}{ Texture classes } & \multicolumn{1}{c}{ Description } & \multicolumn{2}{c}{ Score } \\
\cline { 3 - 4 } & & $\begin{array}{c}\text { Areas dominated } \\
\text { by water erosion }\end{array}$ & $\begin{array}{c}\text { Areas dominated } \\
\text { by wind erosion }\end{array}$ \\
\hline Not very light to average & Loamy sand, Sandy loam, Balanced & 1 & 1 \\
\hline Fine to average & Loamy clay, Clayey sand, Sandy clay & 1.33 & 1.66 \\
\hline Fine & Fine Clayey, Clay loam & 1.66 & 2 \\
\hline Coarse & Sandy to very Sandy & 2 & 2 \\
\hline
\end{tabular}

Table 5. Classes and assigned weighting index for Slope gradient

\begin{tabular}{lccc}
\hline & Classes & Description & Score \\
\hline$<6 \%$ & Gentle & 1 \\
\hline $6-18 \%$ & Not very gentle & 1.33 \\
\hline $19-35 \%$ & Abrupt & 1.66 \\
\hline$>35 \%$ & Very abrupt & 2 \\
\hline
\end{tabular}

Table 6. Classification of soil quality index

\begin{tabular}{ccc}
\hline Class & Description & Range \\
\hline 1 & High quality & $<1.13$ \\
\hline 2 & Moderate quality & 1.13 to 1.45 \\
\hline 3 & Low quality & $>1.46$ \\
\hline
\end{tabular}

\section{Mapping Vegetation quality index (VQI):}

Vegetation quality, according to Basso et al (2000) is assessed in terms of three aspects. Adapted rating values for each of erosion protection, drought resistance and vegetal cover classes were adapted on basis of OSS (2003) as shown in table (7). Vegetation Quality Index was calculated according the following equation, while VQI was classified on basis of the ranges indicated in table (8).

VQI $=(I \text { Ep * I Dr * I Vc })^{1 / 3}$

Where: IEp index of erosion protection, IDr index of drought resistance and IVc index of vegetation cover)

3. Mapping Climatic quality index (CQI): Climatic quality is assessed by using parameters that influence water availability to plants such as the amount of rainfall, air temperature and aridity, as well as climate hazards, which might inhibit plant growth (Thornes,
1995). Table (9) reveals the classification categories of climatic quality index according to OSS, 2003. The Climate quality index is evaluated through the Aridity Index (AI), using the methodology developed by FMA in accordance with the following formula In the current study, rainfall and evapotranspiration data on a metrological station were used to calculate the CQI as follows;

\section{CQI $=$ P/PET}

Where: $\mathrm{P}$ is average annual precipitation and ETP is average annual Potential Evapotranspiration

4. Mapping Environmentally Sensitive Areas (ESA's) to Desertification: ArcGIS9 software was used to map ESA's to Desertification (Kosmas et al, 1999) by integrating all data concerning the soil, vegetation and climate.

Table7. Classes and assigned weighting index for different vegetation parameters

\begin{tabular}{ccccc}
\hline Class & Description & IEp & IDr & IVc \\
\hline 1 & Perennial cultivation & 1.00 & 1.00 & 1.00 \\
\hline 2 & Halophytes & 1.33 & 1.00 & 1.33 \\
\hline 3 & Temporal and orchards, mixed with crop land & 1.66 & 1.33 & 1.66 \\
\hline 4 & Saharan vegetation $<40 \%$ & 2.00 & 1.66 & 1.00 \\
\hline 5 & Saharan vegetation $>40 \%$ & 2.00 & 1.00 & 1.00 \\
\hline
\end{tabular}


Table 8. Classification of vegetation quality index (VQI)

\begin{tabular}{ccc}
\hline Class & Description & Range \\
\hline 1 & Good & $<1.2$ \\
\hline 2 & Average & 1.2 to 1.4 \\
\hline 3 & Weak & 1.4 to 1.6 \\
\hline 4 & Very weak & $>1.6$ \\
\hline
\end{tabular}

Table 9. Classification of Climatic quality index (CQI)

\begin{tabular}{cccc}
\hline Class & Climatic zone & P/PET & CQI \\
\hline 1 & Hyper Arid & $<0.05$ & 2 \\
\hline 2 & Arid & $0.05-0.20$ & 1.75 \\
\hline 3 & Semi Arid & $0.20-0.50$ & 1.50 \\
\hline 4 & Dry Sub-Humid & $0.50-0.65$ & 1.25 \\
\hline 5 & Humid & $>0.65$ & 1 \\
\hline
\end{tabular}

Table 10. Ranges and classes of desertification sensitivity index (DSI)

\begin{tabular}{ccc}
\hline Classes & DSI & Description \\
\hline 1 & $<1.20$ & Non affected areas or very low sensitive areas to desertification \\
\hline 2 & $1.20<\mathrm{DSI}<1.30$ & Low sensitive areas to desertification \\
\hline 3 & $1.30<\mathrm{DSI}<1.40$ & Medium sensitive areas to desertification \\
\hline 4 & $1.40<\mathrm{DSI}<1.60$ & Sensitive areas to desertification \\
\hline 5 & $\mathrm{DSI}>1.60$ & Very sensitive areas to desertification \\
\hline
\end{tabular}

Different quality indices were calculated and displayed as GIS ready maps from which class areas were deduced as shown in table (10). The Desertification Sensitivity Index (DSI) was calculated in the polygonal attribute tables linked with the geographic coverage according to the following equation;

$$
\begin{aligned}
& \text { DSI }=(S Q I * V Q I * C Q I){ }^{1 / 3} \\
& \text { RESULTS AND DISCUSSION }
\end{aligned}
$$

Statistical soil parameters: Table (11) shows the descriptive statistical analysis which indicated that the hydraulic conductivity $(\mathrm{Kh})$ ranged from 0.10 to 0.56 $\mathrm{m} /$ day due to the high percentage of clay content, soil salinity and SAR. Soil salinity varied from 1.35 to 8.00 $\mathrm{dS} / \mathrm{m}$ with low calcium carbonate content (1 to $4.60 \%$ ). Available potassium shows highest variance followed by soil depth available N. Soil salinity shows highest coefficient of variation followed by hydraulic conductivity, SAR, organic matter content, $\mathrm{CaCO}_{3}$ percentage, available $\mathrm{N}$ and soil profile depth.

Terrain analysis: The Digital Elevation Model (DEM) indicated that the elevations varied from 1 to $6 \mathrm{~m}$ A.S.L. The eastern part of the study area has the lowest elevation. The dominant elevation ranged from 1 to $2 \mathrm{~m}$ A.S.L. composed total area 166.88 hect. as shown in map 4 . It is noticeable that the north facing directions (N, NE, NW) is the dominant aspect representing 35.26 $\%$ of the total area, followed by the south facing directions (S, SE, SW) with $28.36 \%$ of the total area.

Semi-Variogram of the soil properties: Semivariograms of individual soil properties were fitted to three models. Soil salinity and sodium adsorption ratio (SAR) were fitted to the Gaussian model; organic matter content and $\mathrm{CaCO}_{3}$ were fitted to the Spherical model and Soil profile depth was fitted to the Exponential model as shown in figure ( $2 \mathrm{a}$ and $\mathrm{b}$ ). The parameters of these models for different soil properties are shown in table (12). It's clear that available potassium has the highest nugget variance followed by depth; which indicates their strong spatial dependence and high inherited variability, (Warrick et al., 1986).

are the ideal for showing the variability and should be considered in any further study for these properties in the area under consideration. Soil profile depth has the highest nugget variance (1.000) which reflects strong spatial dependence and high inherited variability, $\mathrm{Xu}$ and Webster (1984) and Warrick et al (1986). On the other hand, O.M. content has the lowest one which reflects weak spatial dependence and low inherited variability.

\section{Soil thematic maps:}

Salinity: Map (5) shows the distribution of the soil salinity in the study area using weighted average of soil horizons to represent the soil profile. It is clear that salinity is variable and ranged from $<2$ to $8 \mathrm{dS} / \mathrm{m}$, where the dominant soil salinity was $2-4 \mathrm{dS} / \mathrm{m}$ covered an area about $74.41 \%$ of the total area as shown in table (13) followed by $4-8 \mathrm{dS} / \mathrm{m}$ covered an area about $24.75 \%$ of the total area 
Table 11.Statistical characterization of soil properties

\begin{tabular}{ccccccc}
\hline \multirow{2}{*}{ Soil Property } & \multicolumn{7}{c}{ Statistical parameters } \\
\cline { 2 - 7 } & Min & Max & Mean & Variance & St. Dev. & C.V. \\
\hline $\mathrm{pH}$ & 6.99 & 8.40 & 7.56 & 0.115 & 0.34 & 4.48 \\
\hline $\mathrm{Ec}, \mathrm{dS} / \mathrm{m}$ & 1.35 & 8.00 & 3.17 & 2.86 & 1.69 & $\mathbf{5 3 . 2 7}$ \\
\hline $\mathrm{SAR}$ & 2.06 & 11.50 & 5.56 & 5.11 & 2.26 & $\mathbf{4 0 . 6 2 9}$ \\
\hline $\mathrm{CaCO}_{3}, \%$ & 1.00 & 4.60 & 2.61 & 0.58 & 0.76 & $\mathbf{2 9 . 2 9}$ \\
\hline $\mathrm{Kh}, \mathrm{m} / \mathrm{d}$ & 0.10 & 0.56 & 0.30 & 0.02 & 0.14 & $\mathbf{4 6 . 6 6}$ \\
\hline $\mathrm{Av} . \mathrm{K}, \mathrm{ppm}$ & 345.00 & 820.00 & 466.74 & 8380.94 & 91.54 & 19.61 \\
\hline $\mathrm{Av}$. P, ppm & 0.02 & 7.00 & 0.57 & 0.76 & 0.87 & 7.20 \\
\hline $\mathrm{Av}$. N, ppm & 30.00 & 82.50 & 54.69 & 180.35 & 13.43 & $\mathbf{2 4 . 5 5}$ \\
\hline Om, \% & 0.52 & 1.98 & 1.17 & 0.15 & 0.39 & $\mathbf{3 3 . 3 4}$ \\
\hline Clay, \% & 37.00 & 58.50 & 46.94 & 32.25 & 5.67 & 12.09 \\
\hline Silt, \% & 12.50 & 38.00 & 28.73 & 15.99 & 4.00 & 13.92 \\
\hline Sand, $\%$ & 17.50 & 50.00 & 24.33 & 23.16 & 4.81 & 19.78 \\
\hline Depth, cm & 80 & 150 & 120.00 & 905.37 & 30.08 & $\mathbf{2 1 . 3 9}$ \\
\hline
\end{tabular}

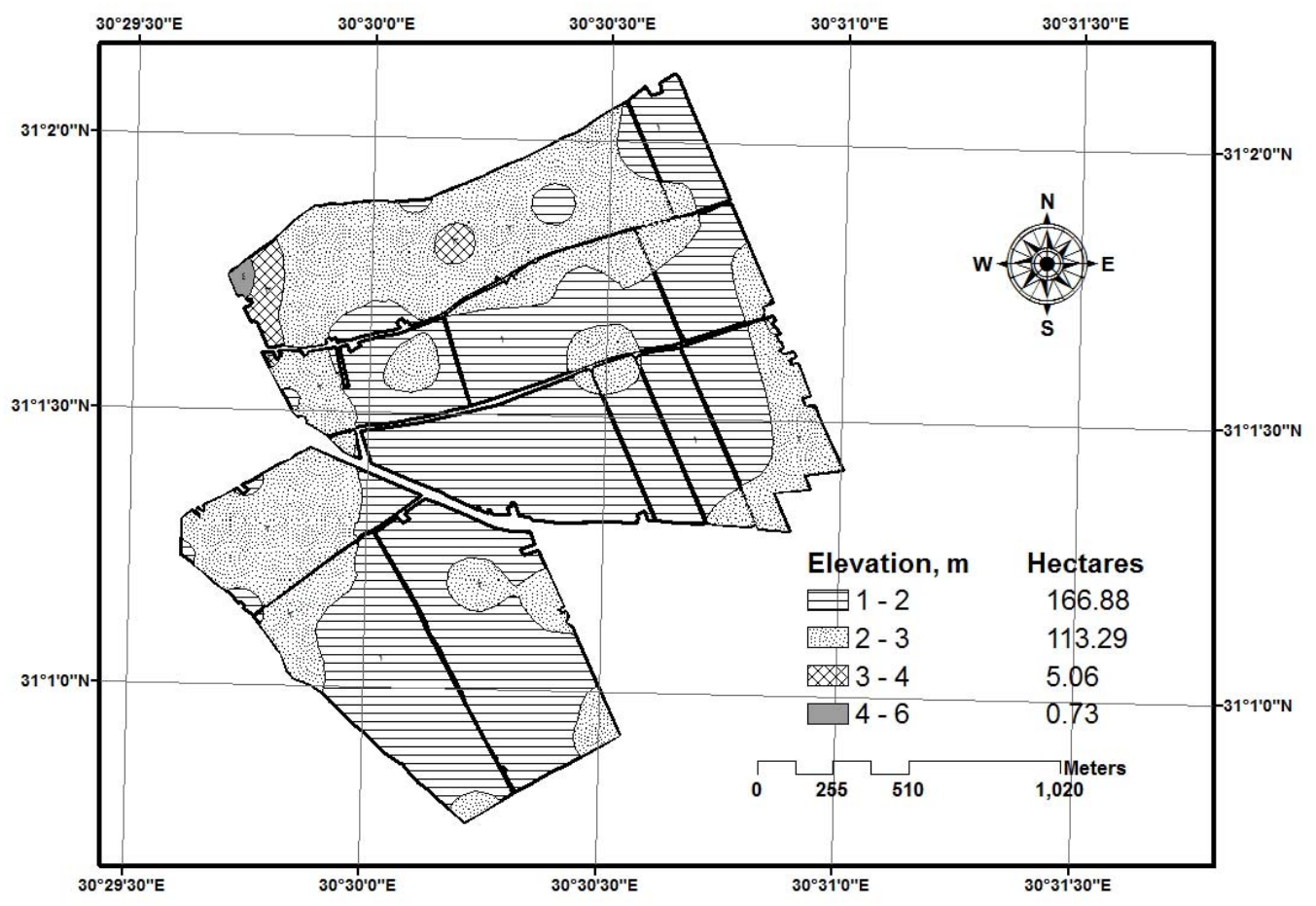

Map 4. Digital Elevation Model and area percentage of study area

Table 12. Semivariogram types and parameters of some soil properties.

\begin{tabular}{lccccc}
\hline \multicolumn{1}{c}{ Soil Property } & Model & Nugget $\left(\mathbf{C}_{\mathbf{o}}\right)$ & Sill (C1) & Range (a) & $\mathbf{r}^{\mathbf{2}}$ \\
\hline $\mathrm{EC}, \mathrm{dS} / \mathrm{m}$ & Gaussian & 0.0100 & 3.550 & 191 & 0.65 \\
$\mathrm{SAR}$ & Gaussian & 0.0100 & 3.970 & 242 & 0.76 \\
$\mathrm{O} . \mathrm{M} \%$ & Spherical & 0.0001 & 0.068 & 927 & 0.89 \\
$\mathrm{CaCO}_{3} \%$ & Spherical & 0.0730 & 0.826 & 751 & 0.81 \\
Depth, cm & Exponential & 1.000 & 1148 & 504 & 0.95 \\
\hline
\end{tabular}


Table13. The area and percentage of salinity classes in the study area

Ec, $\mathbf{d S} / \mathbf{m} \quad$ Area, $\%$

$\begin{array}{cc}<2 & 0.84 \\ 2-4 & 74.41 \\ 4-8 & 24.75\end{array}$

Isotropic Variogram for surface soil salinity

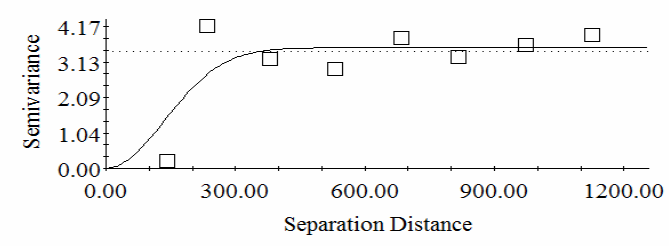

Isotropic Variogram for surface SAR

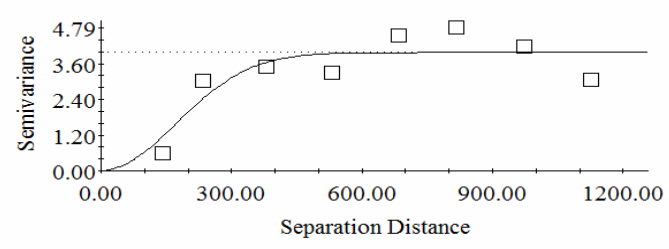

Isotropic Variogram for surface $\mathrm{CaCO} 3$

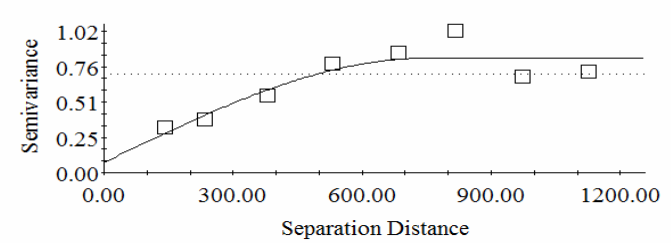

Fig. 2a. Fitted semi-variogram models for $\mathrm{Ec}, \mathrm{SAR}$ and $\mathrm{CaCO}_{3}$.

Isotropic Variogram for surface O.M.

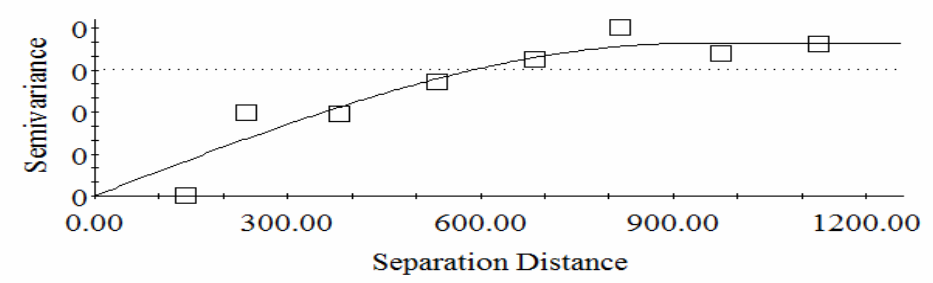

Isotropic Variogram for water depth

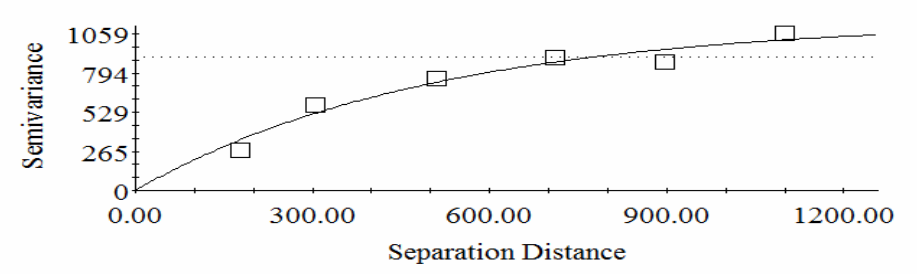

Fig. 2b. Fitted semi-variogram models for O.M. and Water table depth. 
a) Total calcium carbonate: Ranged from $1.00 \%$ to $4.60 \%$ and classified according to FAO, 1990 into two classes. The dominant class in the surface layer was $<$ $2 \%$ which covered an area about $28.96 \%$ of the total followed by $>2 \%$ which covered an area about $21.59 \%$ of the studied area. The same classes and distribution found in the subsurface layer but with an area $30.30 \%$ and $21.72 \%$ of the studied area respectively.

b) Soil Depth: The soil depth ranged from shallow $<100 \mathrm{~cm}$ to deep $>100 \mathrm{~cm}$. It's clear that about $93.98 \%$ of the study area was deep as shown in table (14) and map (6).

Table 14. The area and percentage of the soil depth in the study area

\begin{tabular}{cc}
\hline Depth, $\mathrm{cm}$ & Area, $\%$ \\
\hline$<100 \mathrm{~cm}$ & 6.02 \\
$>100 \mathrm{~cm}$ & 93.98 \\
\hline
\end{tabular}

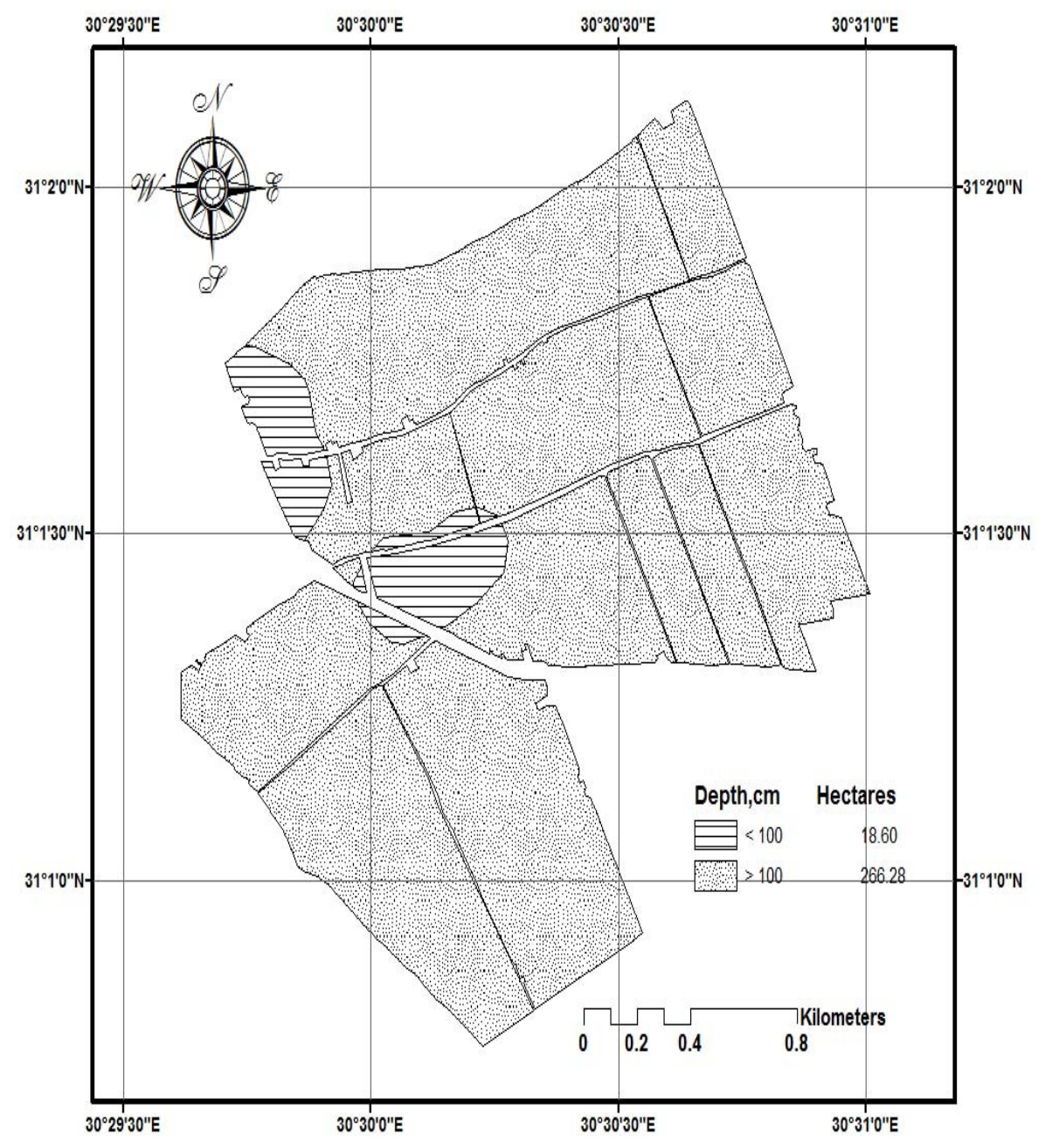

Map 6. Soil depth distribution in the study area. 


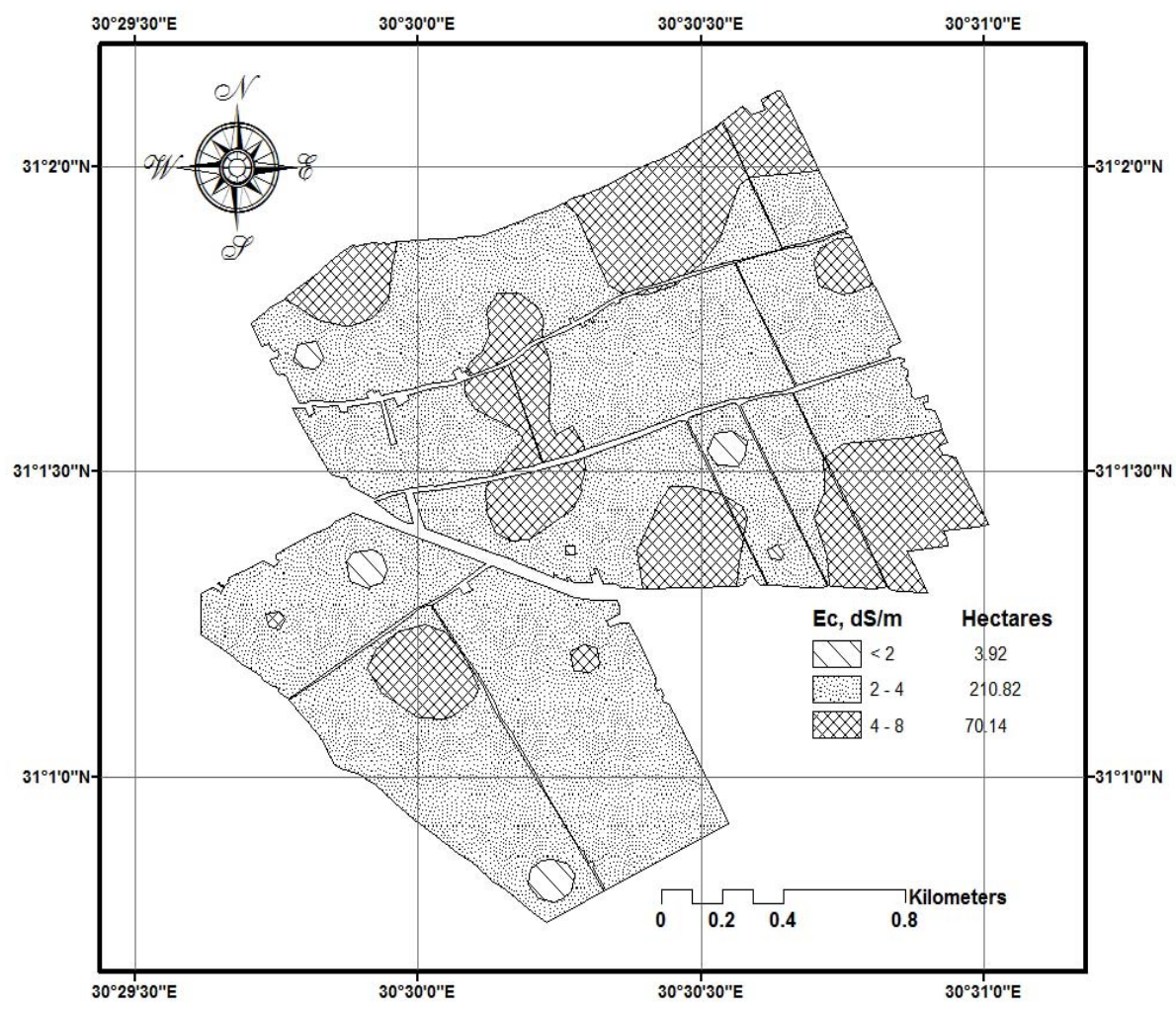

Map 5. Soil salinity classes distribution and area in the study area.

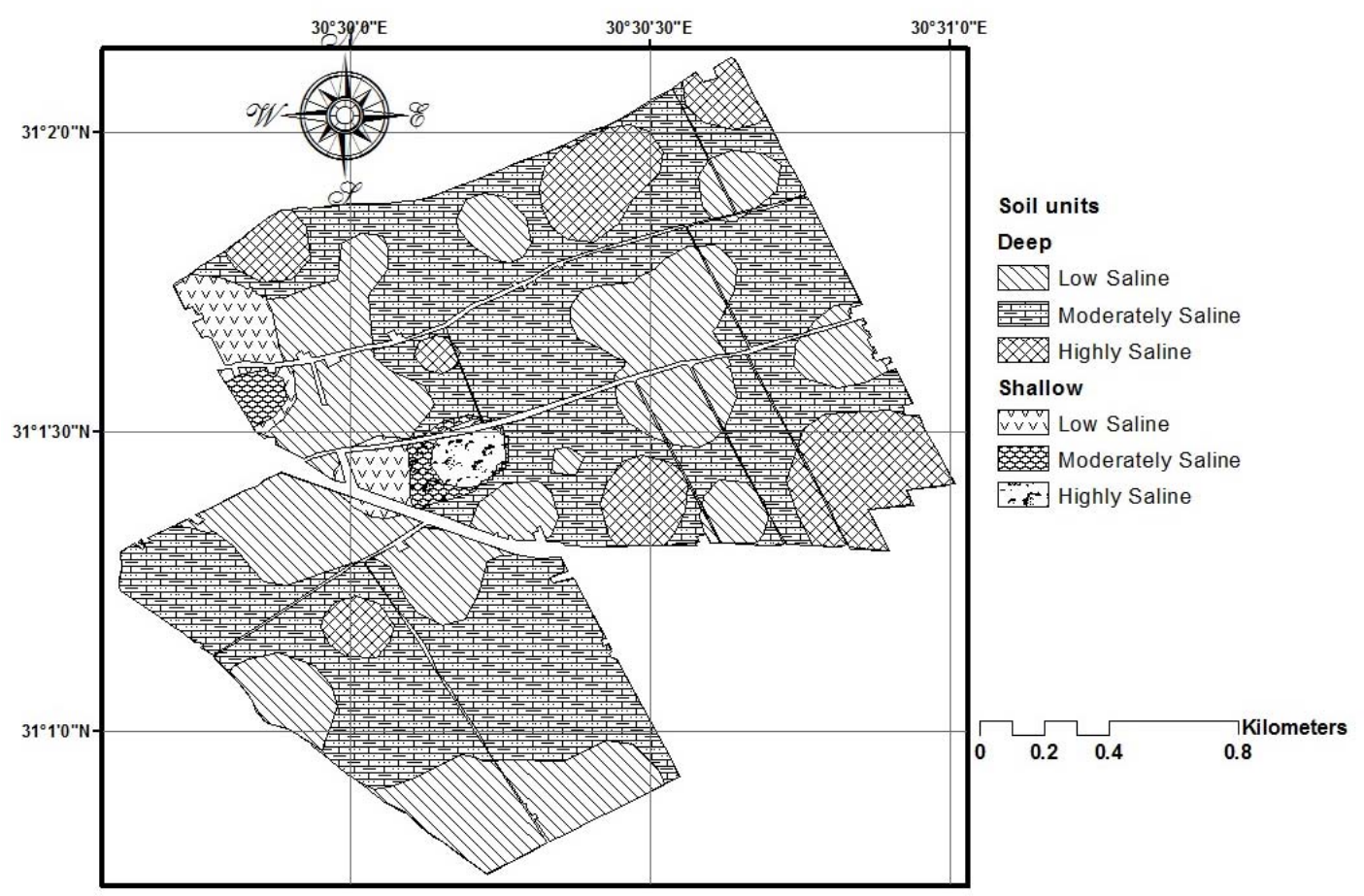

Map 7. Soil mapping units at the study area 
Soil mapping units: The soil mapping units extracted from the overlay of the main soil properties layers in the GIS environment such as soil depth, soil salinity, total calcium carbonate and soil texture. Six soil mapping units found in the study area as shown in map (7). Six soil mapping units were dominated

namely, low saline deep clayey soil (21.10\%), moderately saline deep clayey soil (61.19\%), highly saline deep clayey soil $(9.62 \%)$, low saline shallow clayey soil (2.65\%), moderately saline shallow clayey soil $(5.00 \%)$ and highly saline shallow clayey soil $(0.44 \%)$.

Land capability classes: The (ALES_Arid) model provides prediction for general land use capability for a broad series of possible uses. According to the model prediction, most of the study area was classified as C2 (Kh), which indicated moderate land capability with hydraulic conductivity limiting factor covered an area about $75.80 \%$ of the total area and C2 (Kh, Ec), which indicated moderate capability with hydraulic conductivity and soil salinity as limiting factors covered an area about $24.20 \%$ of the total area. Table (15) illustrates the area and percentage of each land capability class in the study area. Map (8) shows the distribution of each land capability class in the study area.

Table 15. area percentage of land use capability classes in the study area.

\begin{tabular}{lc}
\hline \multicolumn{1}{c}{ Land capability class } & Area (\%) \\
\hline $\mathrm{C} 2, \mathrm{Kh}$ & 75.80 \\
$\mathrm{C} 2, \mathrm{Ec}, \mathrm{Kh}$ & 24.20 \\
\hline
\end{tabular}

Land use planning: The (ALES-Arid) Model was used to predict soil suitability for some common crops cultivated in the study area including: wheat and corn as annual crops; alfalfa as forage perennial, fig and olive as trees perennials. Table (16) summarizes agriculture soil suitability for each soil mapping units for the selected crops and trees.

Quality Index (SOI): According to the geologic map of Egypt, previous studies and field trip of the study area show that the dominant parent material was soft to friable, alluvium. The soil depth were evaluated in the field and

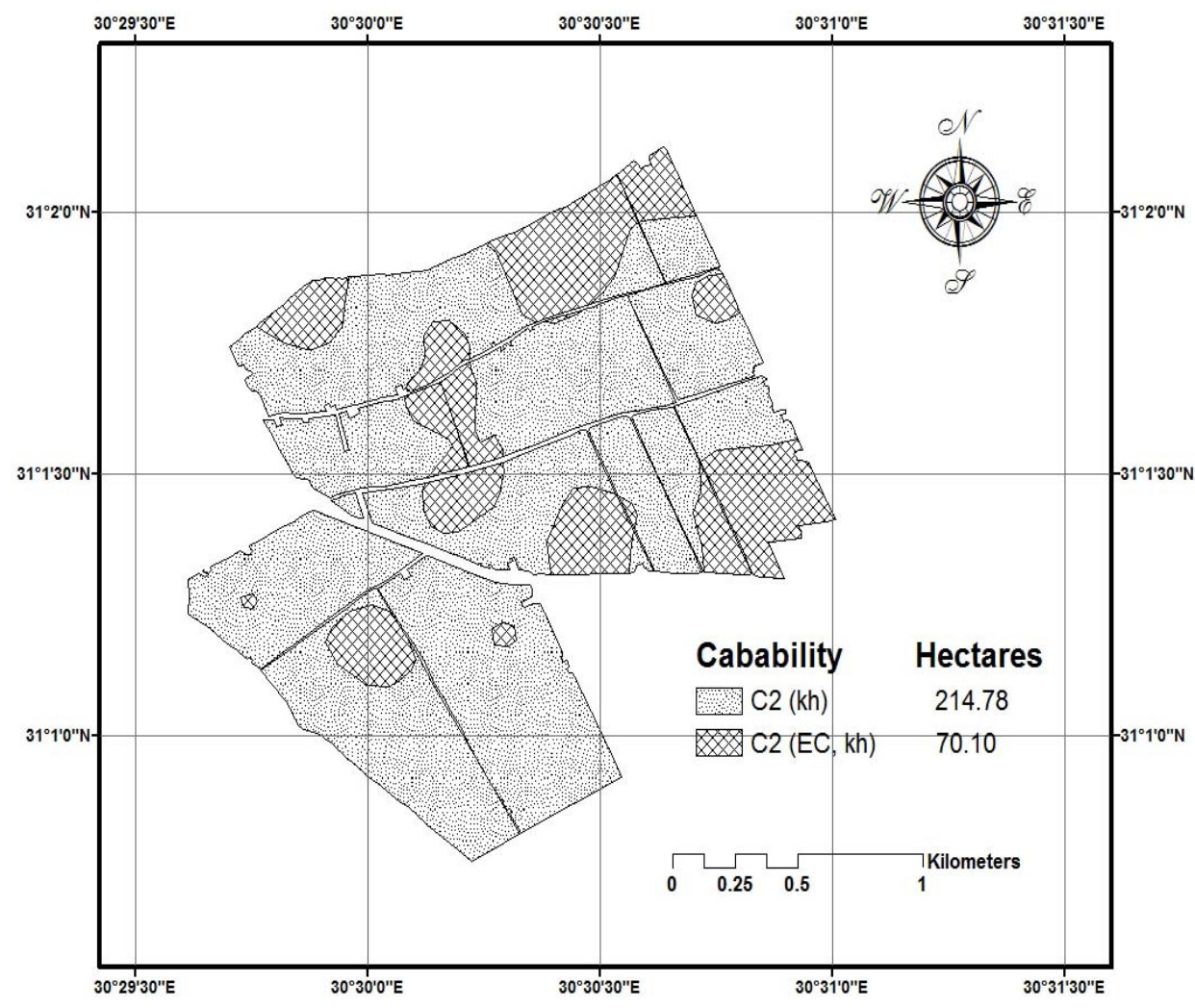

Map 8. Land capability classes of the study area 


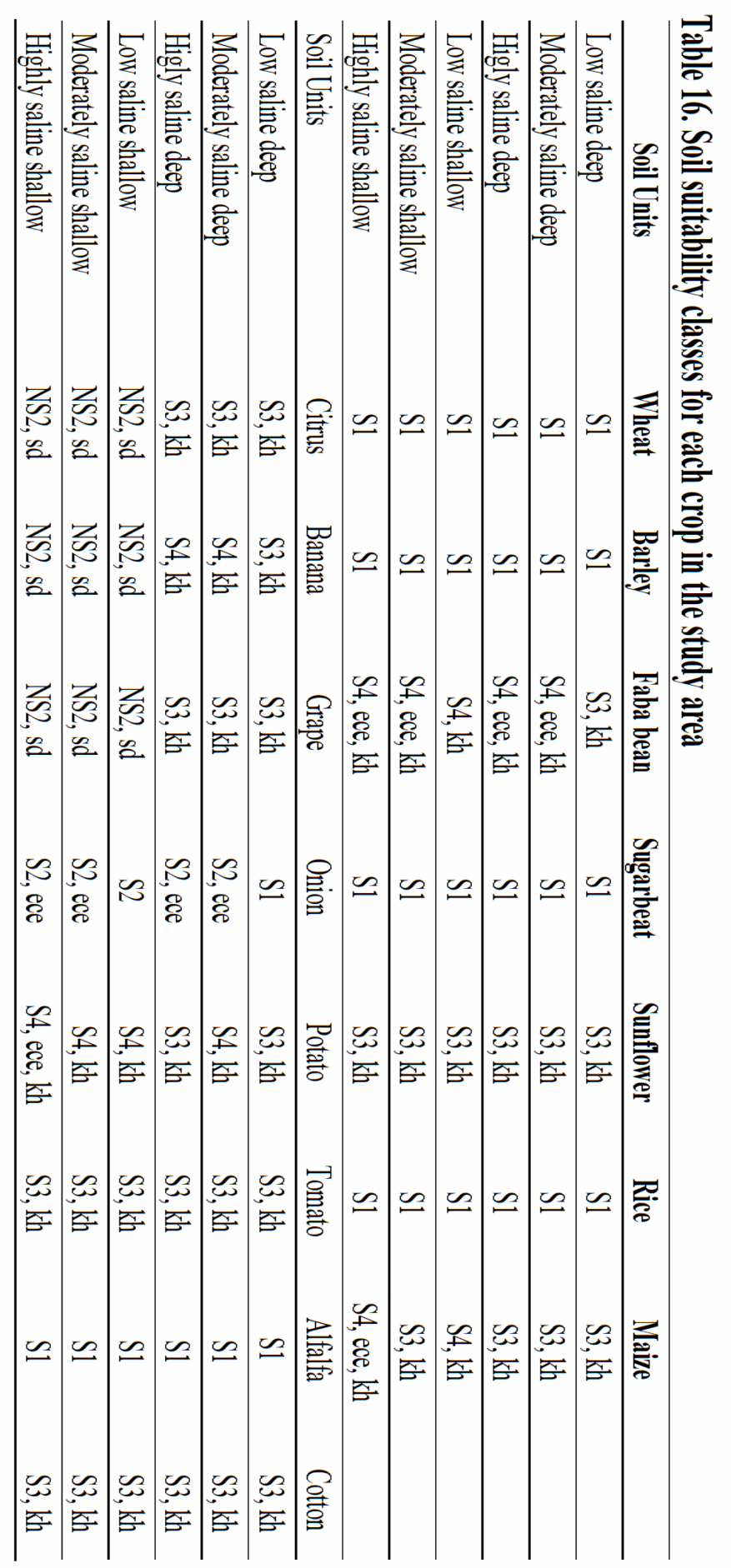


shows that the soil characterized by deep and shallow soil depth. The mechanical analysis of the soil samples shows that the dominant soil texture classes were clayey. The slope gradient was classified, on basis of topographic maps and digital elevation model (DEM). Calculating the soil quality index reveals that the majority of the study area soil $(64.0 \%)$ are characterized by moderate quality (score $=1.18$ ) and the other represent $35.0 \%$ of the study area were high quality.

Vegetation Quality Index (VQI): From the field trip and the questionnaire identifying that the study area vegetation pattern was temporal and orchards, mixed with crop land. Vegetation quality index of this class was given a score evaluating vegetation cover, erosion protection and drought resistance. Calculating the vegetation quality index, on basis of the previous parameters reveal that the area study of the vegetation cover is weak and sensitive to desertification.

Climate Quality Index (CQI): Climatic data (i.e. rainfall and evapo-transpiration) interpolation resulted in obtaining values for both parameters. The climatic sensitivity index was calculated and stored in a GIS. In the study area the average annual rainfall drops down to almost zero. The average annual potential evapotranspiration is relatively high in the study area. The hyper arid climatic conditions characterize the study area region.

Environmentally Sensitive Areas (ESA's) to Desertification: The three previous indices were driven together for the assessment of the environmentally sensitive areas (ESA's) to desertification, on basis of the calculated Desertification Sensitivity Index (DSI). It is clear that most of the study area (64\% of the total area) is very low sensitive to desertification and about $36 \%$ of the total area was not affected areas.

\section{CONCLUSION}

The integration between Geographic information system and modeling plays a key role in quantitative studies of soil properties and land evaluation for different land uses. Geostatistical analysis has a special ability to reduce the number of the samples in the future studies for the study area to reduce the time, efforts, and costs. It's recommended that the quantitative approach for determining the sensitivity for desertification should be adopted and applies to the areas were desertification and environmental deterioration is expected.

\section{REFERENCES}

Abdel Kawy, O. R., 2004. Integrating GIS, remote sensing and modeling for agricultural land suitability evaluation at east Wadi el-Natrun, Egypt. M. SC. Thesis, Faculty of Agriculture, University of Alexandria, Egypt

Bakr, N. David, C. W., Bahnassy, M. H., and El-Badawi, M. M. 2012. Multi-temporal assessment of land sensitivity to desertification in a fragile agro-ecosystem: Environmental indicators. Ecological Indicators 15. 271-280.

Basso F., Bellotti A., Bove E., Faretta S., Ferrara A., Mancino G., Pisante M., Quaranta, G., Taberner M. 1998. Degradation processes in the Agri Basin: evaluating environmental sensitivity to desertification at basin scale. Proceedings International Seminar on 'Indicator for Assessing Desertification in the Mediterranean'. Porto Torres, Italy 18 - 20 September. Edited by G. Enne, M.

Basso F, Bove E, Dumontet S, Ferrara A, Pisante M, Quaranta G, Taberner M. 2000. Evaluating environmental sensitivity at the basin scale through the use of geographic information systems and remotely sensed data: an example covering the Agri Basin (southern Italy). Catena. 40: 19-35.

Briggs D., Giordano A., Cornaert M., Peter D., Maef J. 1992. CORINE soil erosion risk and important land resources in the southern regions of the European Community. EUR 13233. Luxembourg. 97 pp.

Davidson, D., 2002. The assessment of land resources: achievements and new challenges, Australian Geographical Studies, 40:109-128.

Dent, D. and Young, A. (1981). Soil survey and land evaluation. George Allen \& Unwin, London.

Ertugrul Aksoy, Gökhan Özsoy* and M. Sabri Dirim., 2009. Soil mapping approach in GIS using Landsat satellite imagery and DEM data.

http://www.academicjournals.org/ajar/pdf/pdf\%202009/Nov/ Aksoy\%20et\%20al.pdf

European Commission. 1999. The Medalus project Mediterranean desertification and land use- Manual on key indicators of desertification and mapping environmentally sensitive areas to desertification, pp. 84, Eds. C. kosmas, M. Kirkby and N. Geeson, European environment and climate research program - Theme: Land resources and the threat of desertification and soil erosion in Europe (Project ENV4 CT 95 0119).

FAO. 1977. Guidelines: Land evalution for rainfed agriculture. Soil Bulletin 52. FAO, Roma.

FAO. 1985. Guidelines: Land evaluation for irrigated agriculture. Soil Bulletin 55, 212 pp, FAO, Roma.

FAO. 2010. Guidelines for soil profile description. $3^{\text {rd }}$ ed., FAO, Rome.

Gamma Design Inc. 2001. GS+ Geostatistical software user manual. Plainwell, Michigan, USA. 
Heuvelinks, G. and M. Bierkens. 1992. Combinig soils maps with interpolations from point observation to predict quantitative soil properties. Geoderma. 55:1-15.

Klute A.(ed.) 1986. Methods of soil analysis. Part 1. Physical and microbiological methods. $2^{\text {nd }}$ edition. Agron. Monogr. 9. ASA and SSSA, Madison, WI.

Kosmas C., Poesen J., Briasouli H. 1999. Key indicators of desertification at the ESA a scale. In 'Manual on Key Indicators of desertification and Mapping Environmentally Sensitive Areas to Desertification'. MEDALUS III Project. King's College, London.

Isaaks, E.H., and R.M. Srivastava. 1989. An Introduction to Applied Geostatistics. Oxford University Press, New York.

Iuliana Cornelia., 2011. Methods for natural land mapping units delineation for agricultural land evaluation, Lucrări ştiinţifice - vol. 54, Nr. 1/2011, seria Agronomie.

http://www.revagrois.ro/PDF/2011/paper/2011-54\%281\%2910-en.pdf.

McKenzie, N. and M. Austin. 1993. A quantitative Australian approach to medium and small scale surveys based on stratigraphy and enviromental correlation. Geoderma. 57:329-355.

OSS. 2003. Map of sensitivity to desertification in the Mediterranean basin- Proposal for the methodology for the final map, Rome: Observatory of the Sahara and Sahel (OSS). Basso F., Bove E., Dumontet S., Ferrara A., Pisante M., Quaranta, G., Taberner M. 2000. Evaluating Environmental Sensitivity at the basin scale through the use of Geographic Information Systems and Remote Sensed data: an example covering the Agri basin (southern Italy). Catena $40: 19-35$

Özsoy G, Aksoy E (2007). Characterization, classification and agricultural usage of vertisols developed on neogene aged calcareous marl parent materials. J. Biol. Environ. Sci. 1(1): 5-10. Cited from Soil mapping approach in GIS using Landsat satellite imagery and DEM data. http://www.academicjournals.org/ajar/pdf/pdf\%202009/N ov/Aksoy\%20et\%20al.pdf.

Page, A. L.; Miller, R. H. and Keeny, R. 1982. "Methods of soil analysis. Part2. Chemical and microbiological properties. Agron. Monograph No. 9, ASA, Madison, WI, USA.
Rey, J. and F. Ovalles . 1997. Transferencia del modelo de variación de propiedades de suelo entre dos áreas análogas. Memorias del XIV Congreso Venezolano de la Ciencia del Suelo. Venezuela, 2 al 7 de Noviembre de 1997. Cited from Modelling of spatial variability of soil map delineations using geographical information systems.

http://natres.psu.ac.th/Link/SoilCongress/bdd/symp17/1536t.pdf

Storie, R. E. 1964. Soil and land classification for irrigation development. Transac. $8^{\text {th }}$ intern. Congress of Soil Sci., Bucharest, Roma, 873-882.

Sys, C., 1975. Guidelines for the interpretation of land properties for some general land utilization types. In report on the technical consultation land evaluation in Europe. Soils Bulletin No.29, FAO, Roma p. 107-118.

Sys, C., Van Ramst, E., Debaveye, J., and Beernaert, F., 1993a. Land evaluation. Part III, Crop requirements. International Training Center (ITC) for post-graduate soil scientists. University Ghent.

Sys, C., Van Ramst, E., Debaveye, J., and Beernaert, F., 1993b. Land evaluation. Part II, Methods in land evaluation. General administration for development cooperation, Agric. Pub. No. 7, ITC. Uni. Ghent.

Thornes J.B. 1995. Mediterranean desertification and the vegetation cover. In EUR 15415 - "Desertification in a European context: Physical and socio-economic aspects", edited by R.Fantechi, D.Peter, P.Balabanis, J.L. Rubio. Brussels, Luxembourg: Office for Official Publications of the European Communities. 169- 194

Warrick, A. W, D. E. Mers, and D. R. Nielsen. 1986. Geostatistical methods applied to soil science. In A. Klute (ed) Methods of soil analysis. Part 1: Physical and

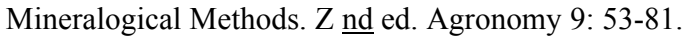

Wagner Lourenco R, Landim PMB, Henrique Rosa A, Roveda JAF, Martins ACG, Fraceto LF (2010) Mapping soil pollution by spatial analysis and fuzzy classification. Environ Earth Sci 60: 495-504

Webster, R. 1977. Quantitative and numerical methods in soil classification and survey. Clarendon press, Oxford.

Wilding, L.P. and Drees, L.R. 1983. Spatial variability and pedology. pp.83-116. In: L.P. Wilding et al. (eds). Pedogenesis and soil taxonomy. 1:concepts and interpretation. Elsevier, Amsterdam.

Xu, J. Webster, R., 1984. A geostatistical study of top soil properties Lin Zhangwu country. China Catena 11, 13-26. 


\section{पad}

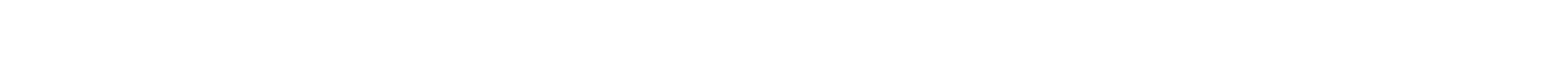

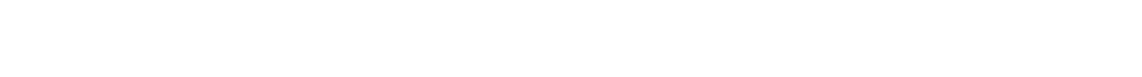

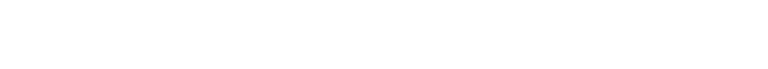

تورزيجها Gaussian Model لما بالنبة لـتوى الزية من كريونت

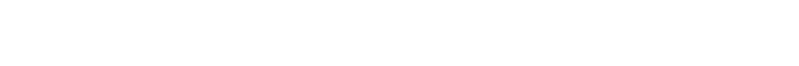
Dpherical Model

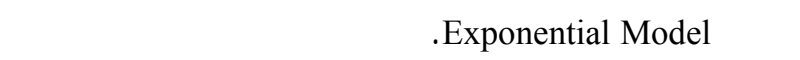

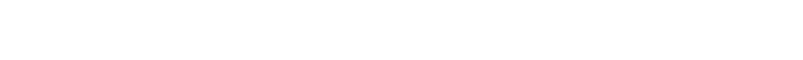

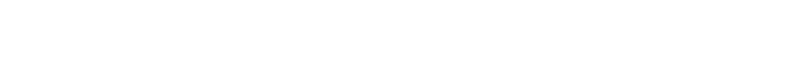

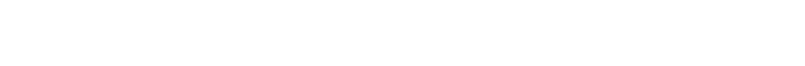

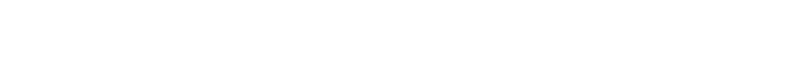

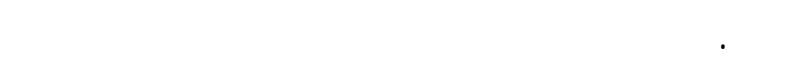

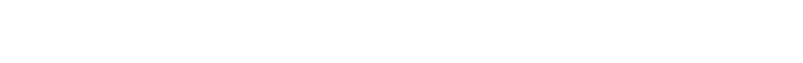

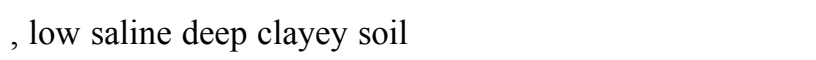
(21.10\%), moderately saline deep clayey soil (61.19\%), highly saline deep clayey soil (9.62\%), low saline shallow clayey soil $(2.65 \%)$, moderately saline shallow clayey soil $(5.00 \%)$ and highly saline shallow clayey .soil $(0.44 \%)$

من خلل نقيم القدرة الاتاجية للوحدات الارضية الهختلف

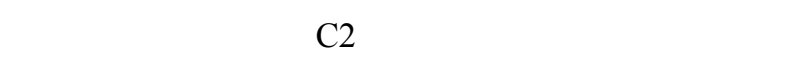

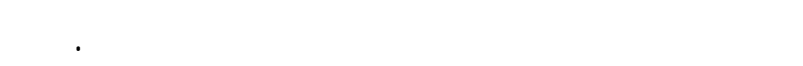

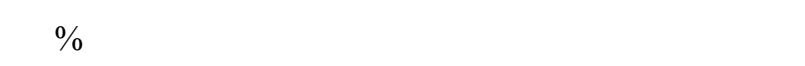

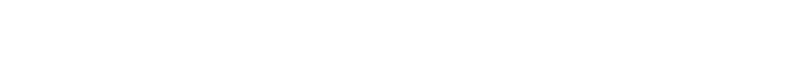

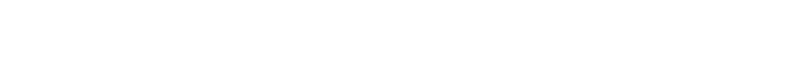

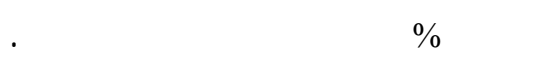

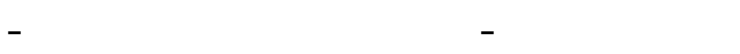

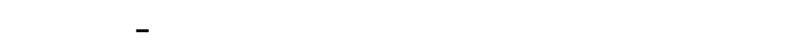

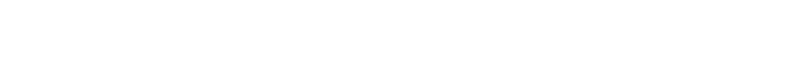

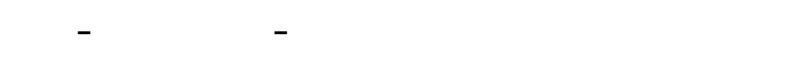

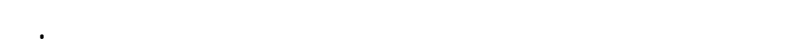

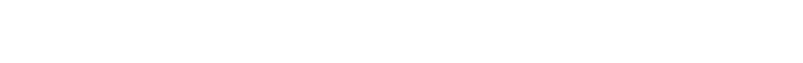

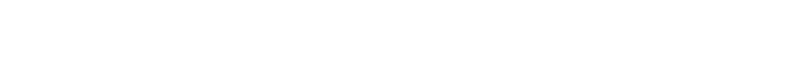

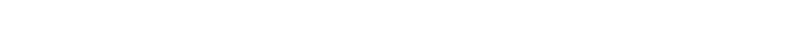

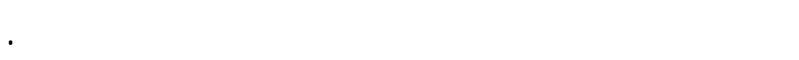

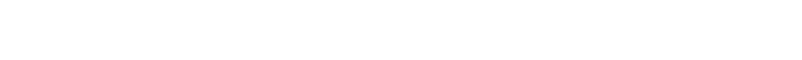

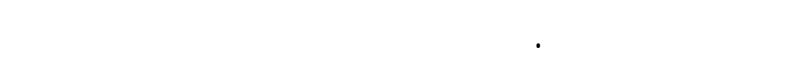

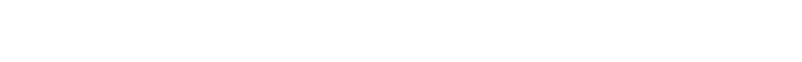

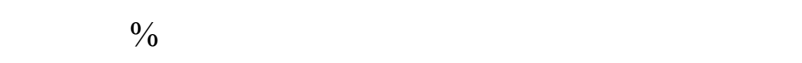

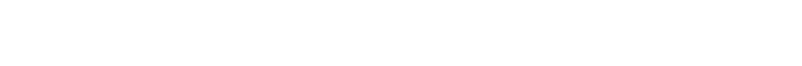

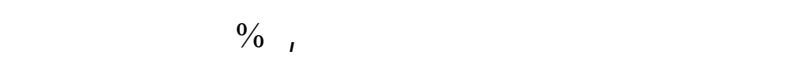

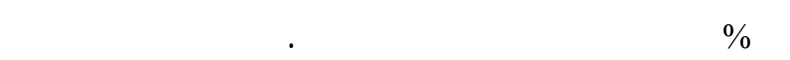

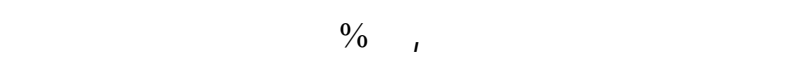

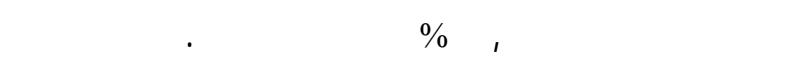

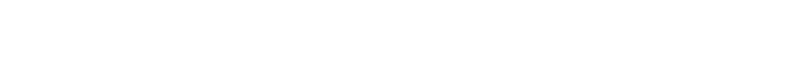

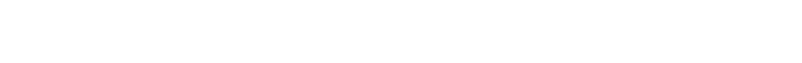

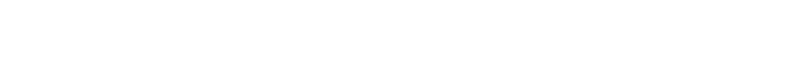

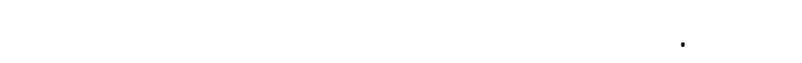

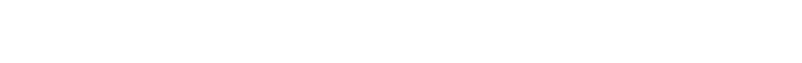

